This is the Accepted Version of a forthcoming article that will be published by Sage in Critical Sociology: https://uk.sagepub.com/en-gb/eur/journal/critical-sociology

Accepted Version downloaded from SOAS Research Online: http://eprints.soas.ac.uk/22614

\title{
Thirteen Things You Need to Know About Neoliberalism
}

\section{Ben Fine}

Department of Economics

SOAS, University of London, UK

bf@soas.ac.uk

\section{Alfredo Saad-Filho}

Department of Development Studies

SOAS, University of London, UK

as59@soas.ac.uk

\section{ABSTRACT}

This article examines the theories and practices of neoliberalism across thirteen aspects of ('things you need to know about') neoliberalism. They include the argument that neoliberalism is not reducible to a cogent ideology or a change in economic or social policies, nor is it primarily about a shift in the relationship between the state and the market or between workers and capital in general, or finance in particular. Instead, neoliberalism is a stage in the development of capitalism underpinned by financialisation. Neoliberalism by its nature is highly diversified in its features, impact and outcomes, reflecting specific combinations of scholarship, ideology, policy and practice. In turn, these are attached to distinctive material cultures giving rise to the (variegated) neoliberalisation of everyday life and, at a further remove, to specific modalities of economic growth, volatility and crisis. Finally, this paper argues that there are alternatives, both within and beyond neoliberalism itself.

Keywords: Neoliberalism, Capitalism, Crisis, Keynesianism, Marxism. 


\section{Introduction}

Oh no, not another piece on neoliberalism, synthesising what has gone before, adding its own particular angle, and thereby compounding the confusion as much as clarifying what has gone before. ${ }^{1}$ And, what's more, written with a popular title along the lines of Ha-Joon Chang's (2011) 23 Things They Don't Tell You About Capitalism. But appearances can be deceptive. For, whilst this is a stocktaking exercise, delivered to some degree in popular and stark form, it gains depth from three sources. One is longstanding scholarship on neoliberalism itself. ${ }^{2}$ Another is being able to view, and to present, neoliberalism in light of the global crisis. The third is to have illustrated the nature of neoliberalism through comparative case studies around housing, health, pensions and water, themselves situated in the broader context of study of the impact of financialisation on economic and social functioning. ${ }^{3}$

This intellectual exercise is both significant and timely because the current 'age of neoliberalism' has already lasted beyond one generation - exceeding the lifetime of the preceding Keynesian 'golden age' - and there are no signs that it is about to give way. The solidity of neoliberalism, its continuing ability to renew itself and intensify its hold on governments and societies despite economic volatility and the depth of the current crisis, warrants recognition and detailed investigation. We offer our contribution in what follows.

The first thing you need to know about neoliberalism is that it represents a new stage in the development of capitalism emerging in the wake of the post-war boom. 
In the social sciences literature, neoliberalism has generally been understood in four closely-related and not always easily separable ways: (a) as a set of economic and political ideas inspired, unevenly and often inconsistently, by the (neo-)Austrian School and monetarism; ${ }^{4}$ (b) as a set of policies, institutions and practices inspired and/or validated by those ideas $;^{5}$ (c) as a class offensive against the workers and the poor led by the state on behalf of capital in general and finance in particular (this attack is normally justified by recourse to neoliberal ideas and carried out through so-called economic 'adjustment', especially in developing but increasingly in developed countries in crisis), ${ }^{6}$ and (d) as a material structure of social, economic and political reproduction underpinned by financialisation, in which case neoliberalism is the current phase, stage, or mode of existence of capitalism. Each conceptualisation of neoliberalism necessarily involves a further issue: does this concept offer anything of substance or coherence in understanding the contemporary world as opposed to 'free market' capitalism, post-fordism (underpinning postmodernism), the 'knowledge economy', the ever popular consumer society, or whatever? ${ }^{7}$

Our own starting point is to characterise neoliberalism in light of approach (d). This immediately raises three further questions. First is how do we define a stage of capitalism. This is done through the distinctive ways in which economic reproduction (the accumulation, distribution and exchange of value) is organised and reorganised and its implications for social reproduction (the structures, relations, processes and agents that are not directly or predominantly economic, including the political and the ideological). As Dardot and Laval (2013, p.14) rightly put it, 'the originality of neoliberalism is precisely its creation of a new 
set of rules defining not only a different "regime of accumulation", but, more broadly, a different society'.

Second is how do we characterise previous stages of capitalism. This is to some degree academic as there tends to be uniformity over the periodisation of capitalism into separate stages even if slightly different criteria from ours are used to do so. ${ }^{8}$ Some sort of laissez-faire period in the nineteenth century is presumed to give way to a more monopolistic stage in the first half of the twentieth century which then passes to a stage in which state intervention is significant, conventionally termed the Keynesian or Fordist period. ${ }^{9}$ More significantly, stages of capitalism are distinguished by global and not merely a collection of national conditions, so it would be inappropriate to start inductively from the classification of countries into those that are more or less (neo)liberal, Keynesian or whatever. Rather, different countries exist within, and influence, the dominant stages of global capitalism in different ways, and the same is true of the economic, the political and the ideological more generally at different levels and in different arenas.

The third issue is why should neoliberalism be considered a new and separate stage of capitalism. Our answer is to be found throughout what follows but is fundamentally based upon the insight that the most salient feature of neoliberalism is financialisation. As is shown in the fifth thing, the rise of financialisation over the past thirty years, defined as the intensive and extensive accumulation of interest-bearing capital, has transformed profoundly the organisation of economic and social reproduction. These transformations include not only outcomes but the structures, processes, agencies and relations through which those outcomes are determined across production, employment, international integration, the state and ideology. The term financialisation, then, encapsulates the increasing role of globalised 
finance in ever more areas of economic and social life. In turn, financialisation underpins a neoliberal system of accumulation that is articulated through the power of the state to impose, drive, underwrite and manage the internationalisation of production and finance in each territory, often under the perverse ideological veil of promoting non-interventionism.

Our favoured approach, then, not only claims that neoliberalism is the current stage, phase or mode of existence of capitalism but also explains how it should be understood as such. It also implies that the starting point in specifying neoliberalism must have both logical and historical content. The former concerns the nature of economic reproduction under neoliberalism, while the latter focuses on the (uneven) ways in which neoliberalism exists across different countries including both social and economic reproduction. For, as will be seen under the tenth thing, neoliberalism is distinctive but not homogenising. Instead, it fosters diversity and differentiation underpinned by common aspects. It is the latter that have to be identified in the first instance, together with their internal contradictions, tensions and sources of dynamics and, consequently, potential to realise uneven outcomes and the mechanisms and determinants through which they do so in specific instances. In contrast, the commonly held presumption that neoliberalism is homogenising is grounded at an excessively concrete level and in a selective manner, either missing out on the diverse consequences of the common drivers of neoliberalism, or inevitably concluding that it is an incoherent specification of contemporary capitalism in light of this diversity. ${ }^{10}$

This approach to neoliberalism informs a specific understanding of two key features of the contemporary political economy. These are, first, that financialisation has transformed the global patterns of growth. The rates of investment and GDP growth in the advanced economies have tended to decline since the crisis of the so-called Keynesian, Fordist and 
social democratic 'golden age', regardless of the unprecedentedly favourable conditions for capital accumulation, in part imposed through neoliberalism itself. These conditions include the West's victory in the Cold War and the collapse of most nationalist movements in the Global South, and the closely related liberalisation of trade, finance and capital movements, the provision of unparalleled support to accumulation by competing states, the containing of taxation, transfers and welfare provision in most countries, the secular decline in the power of trade unions, peasant movements, left parties and social movements (the traditional sources of resistance within previous forms of capitalism), and the unprecedented ideological hegemony of a bogus but vociferous 'free market' capitalism. Finally, the unprecedented availability of new technologies serves as a potential source of productivity increase, alongside significant increases in the global capitalist labour force, not least with China's integration into the capitalist world economy. Instead of thriving on the basis of these conditions, global accumulation in the core countries has been hampered by continuing instability and, since 2007, by the deepest and longest economic crisis since the Great Depression.

The second key feature is that neoliberal patterns of production, employment, finance and consumption have simultaneously sustained impressive rates of investment and GDP growth in particular regions, with Northeast and Southeast Asia to the fore and, more recently, the transformation of China into the assembly hub of the world. ${ }^{11}$ This is far from suggesting that neoliberalism fosters an unproblematic 'global convergence'. Rather, it creates new patterns of uneven and combined development, in which unparalleled prosperity within and across countries and regions, and for specific social strata (possibly identified as financial or other elites or oligarchs, the top $1 \%$, the top $0.01 \%$ or whatever), both, coexist with new patterns of poverty as well as its reproduction in areas where it already prevailed. 
The second thing you need to know about neoliberalism is that it is not reducible to a cogent ideology, but it is attached to a wide spectrum of ideas. These ideas display a changing relevance in rationalising current conditions and selected policies, quite apart from their leverage over state policy and in confining and steering the political and other contestations.

Neoliberalism draws heavily, if at times indirectly, upon the Austrian tradition of Ludwig von Mises, Friedrich von Hayek and their neo-Austrian successors, and the US monetarist school associated with the Department of Economics, University of Chicago in general and with Milton Friedman in particular. They argue, albeit in sharply dissimilar and logically incompatible ways, that differently endowed property-owning individuals exchanging goods, services and information in minimally regulated markets constitute the most desirable form for allocating resources and should prevail over an interventionist role of the state and, even if less apparent in popular discourse, democratic processes: the neoliberal ideology of free markets can never entirely part company with its antithesis in some respects, the authoritarian state. ${ }^{12}$

Despite their shared purposes and conclusions, even casual examination reveals considerable tensions between these scholarly underpinnings of neoliberalism. For example, while the (neo-)Austrians emphasise the inventive and transformative subjectivity of the individual and the spontaneous emergence of an increasingly efficient order through market processes, neoclassical economics focuses on the efficiency properties of a static equilibrium achieved entirely in the logical domain on the basis of unchanging individuals, resources and 
technologies and, possibly, mediated by the semi-divine intervention of the 'auctioneer'. Nor does either capture the political economy and moral philosophy associated with Adam Smith, despite their obsessive rhetorical recourse to the 'invisible hand', with its meaning and rationale subject to varieties of (mis)interpretations. ${ }^{13}$

The analytical inconsistencies and policy failures of monetarism have been exposed in merciless detail by Keynesian and heterodox economists, but these shortcomings have been largely ignored by mainstream economists, policymakers and the media. ${ }^{14}$ They promoted, instead, a populist understanding of 'competitiveness', 'individual freedom' and 'democracy' that has validated neoliberal policy reforms and repression of opposition in country after country, while also providing reassurance that the neoliberal reforms spawn the best of all possible worlds.

Despite, or because of, its impressive strengths, neoliberal ideology remains too fragmented to provide a coherent representation of society. It offers, instead, an individualist, formally egalitarian, meliorist and universalist conception of self and society. This worldview justifies a set of loosely articulated finance-friendly state policies and practices giving neoliberalism a semblance of coherence in the realm of ideas, and considerable resilience in practice: these policies cannot be contested easily, for the neoliberal restructuring of the economy and society not only narrows drastically the scope for, and directions of, debate, but also hollows out the institutional channels from which alternatives could emerge. These limitations are notable, for example, in stridently defended privatisations that are habitually awarded to, or create, monopolies, and in decentralisation of state provision, in which a leading thrust is to 'devolve' responsibility for delivery to lower levels of administration (claiming also to democratise), whilst not providing sufficient resources to allow for 
provision to meet requirements whether formal or otherwise, and imposing the requirement to rely on private suppliers (see ninth thing).

3

The third thing you need to know about neoliberalism is that it is not fully nor appropriately understood as the mirror image of, or a reaction against, Keynesianism, itself often inadequately seen as the explanation for the post-war boom.

Although almost every area of economic and social reproduction has been reconfigured under neoliberalism (see first and second things), neoliberal ideology tends to induce a shallow opposition between neoliberalism and Keynesianism, as if the former could be reduced to the rollback of the latter. In turn, Keynesianism is often described through 'state intervention' and collectivised forms of provision, including the short-run macroeconomic manipulation of effective demand, the welfare state, nationalised industries, some measure of planning and social contracts, which might progress to socialism through incremental reform.

It may be appealing to see neoliberalism as the counterpart to this conception of Keynesianism, offering a swing in the balance between market and state provision (see fourth thing). Even acknowledging that Keynesianism is associated with more or less progressive forms of state expenditure and intervention, the post-war boom was not driven by a bland and presumably incremental socialism but by economic and social restructuring with internationalisation of all forms of capital to the fore, especially that of productive capital, supported by (mainly US-dominated) finance, with a heavy role for the state in promoting 
such restructuring through both national and international corporate champions. ${ }^{15}$ In turn, Keynesianism was driven to collapse because of the economic and social transformations that it engendered and supported, and the contradictions embodied in its own policies. ${ }^{16}$ The simplistic dualism between Keynesianism and neoliberalism fails to acknowledge the broadly spread and deeply rooted transformations in economic and social reproduction and their reflection in the profound changes across each of scholarship, ideology and policy in practice. $^{17}$

This failure to recognise the complex relationship between neoliberalism and Keynesianism has fed two additional illusions. One strand of thought, especially within Marxism, sees the emergence of neoliberalism in general and financialisation in particular as either the epiphenomenal consequence of, or the functionalist response to, the still unresolved crisis of Keynesianism. ${ }^{18}$ Such reductionism is insufficient because it simply sets aside three decades of global restructuring of production, employment, trade, finance, ideology, state and society, and overlooks the role of financialisation (see fifth thing) in promoting and supporting the contemporary (neoliberal) forms of accumulation and the social reproduction that accompanies it. ${ }^{19}$

The antithetical illusion, associated with social democracy, is that a return to Keynesianism can restore more favourable economic and social conditions today. Even though higher taxes, controls on trade, domestic finance and capital flows, expanded social provision and the fine-tuning of aggregate demand can help to address competing short-term macroeconomic objectives and promote short-term improvements in economic performance and social welfare, these policies would have only limited bearing on the long-term performance and underlying dynamics of the global economy and, even if achievable today, 
would remain hostages to neoliberal imperatives. Highlighting the contradictions of neoliberalism by contrast with (the strengths and virtues of) what existed before is an important analytical task in its own right, but it will neither reveal alternatives to neoliberalism nor make the limitations of Keynesianism disappear in practice.

It follows that neoliberalism and the potential for overcoming it cannot be encapsulated in conventional debates in macroeconomics, which express the rivalry between more or less sophisticated versions of monetarism and Keynesianism over whether and how to manipulate effective demand and other macroeconomic variables in order to deliver rapid and stable accumulation. ${ }^{20}$ This bypasses almost entirely the problems of economic and social restructuring and reproduction. Even if alternative policies are appropriately identified, the means to secure them against neoliberal imperatives remains unaddressed as neoliberals themselves would suggest in terms of the imperatives of the market, globalisation and so on.

The fourth thing you need to know about neoliberalism is that it is not primarily about a (possibly pendular) shift in the relationship between the state (or the Polanyian social or collective) and the market.

Market-state dualism is insufficient because neoliberalism is not defined by the withdrawal of the state from social and economic reproduction. ${ }^{21}$ As Wacquant $(2009$, p.307) suggests: 
A central ideological tenet of neoliberalism is that it entails the coming of 'small government': the shrinking of the allegedly flaccid and overgrown Keynesian welfare state and its makeover into a lean and nimble workfare state ... stressing self-reliance, commitment to paid work, and managerialism ... [But] the neoliberal state turns out to be quite different in actuality.

Under neoliberalism state institutions intervene upon and through markets and other institutions in specific ways that tend to extend and/or reproduce neoliberalism itself. ${ }^{22}$ Exactly the same is true of other systems of accumulation, not least those attached to the Keynesian, developmental or Soviet-type states that are presumed to have been more interventionist. ${ }^{23}$ In all these cases, the roles of 'the state' and 'the market' (unduly undifferentiated) cannot be usefully identified through their simplistic opposition. Instead, the relevant patterns of accumulation, restructuring and social and economic reproduction can be understood only through relatively concrete and historically specific analyses. These must include the interaction, contestation and co-operation among specific institutions within, across and beyond that putative divide. Those processes are themselves heavily influenced by, but not reducible to, the underlying economic, political and ideological (class) interests that act upon and through such institutions.

In practice, then, first, much has been achieved through state provision in the past, and this has itself become the basis for privatisation, for example, in terms of availability of productive facilities. The scope for such achievements can only have been enhanced over time through improved technological capabilities and new management techniques. Yet, these successes are rarely if ever recognised, while public provision is invariably and arbitrarily deemed to be inferior to private provision often on the basis of casual or flawed 
studies, that rarely even consider firm and market structure, finance, degree of monopoly and so on. ${ }^{24}$

Second, state intervention has been transformed rather than simply 'reduced' under neoliberalism (see sixth thing). Currently, while the overall logic of state policies and interventions remains to promote economic and social reproduction and the restructuring of capital, the interests and role of finance have increasingly come to the fore either directly or indirectly. Such is evident, for example, from the policy responses to the global crisis and the continuing recession; but it is equally characteristic of the policies implemented over the entire neoliberal period, as the interests of private capital in general and of finance in particular have been favoured by the state (see eighth thing).

5

The fifth thing you need to know about neoliberalism is that it is underpinned by, although not reducible to, financialisation. ${ }^{25}$

Whilst seeing neoliberalism as tied to financialisation is pushing against an open door, especially in the wake of the current global crisis, financialisation itself has often been imprecisely defined and variously understood across a burgeoning literature. In much of this literature, financialisation is merely a buzzword reflecting the greater significance of finance in economic and social reproduction in recent decades, and the (closely related) growth and proliferation of financial assets. However, if financialisation is defined as the increasing presence and influence of finance, then, given its remarkable rise over the last thirty years, it is tautological to define neoliberalism as attached to financialisation. This leaves open the 
question of the drivers and contradictions of financialisation and neoliberalism, and how they should be addressed in terms of analytical content and their effects.

Our more specific view of financialisation focuses, instead, on the role of finance as (interest-bearing) capital and not just as financial or credit relations in general. It is precisely in this respect that financialisation marks a departure from the past both in the scale and in scope of financial activity in pursuit of financial returns at the expense of production. In this sense, a mortgage, for example, remains a simple (transhistoric) credit relation between borrower and lender. However, it becomes embroiled in financialisation once that mortgage obligation is sold on as part of some other asset, which becomes routinised only under neoliberalism. With such financialisation spread more generally, so grows the influence of finance over the control of resource allocation - including the flows of money, credit and foreign exchange and, correspondingly, the level and composition of output, employment, investment and trade, and the financing of the state - by money-capital embodied in an array of (more or less esoteric) financial assets. ${ }^{26}$ Those assets are created, held, traded and regulated by specialist institutions that, under neoliberalism, are integrated in a distinctly USled global financial system. ${ }^{27}$

The creation and circulation of these financial assets is an intrinsically speculative activity that tends to become unmoored from the constraints of production, even though this autonomy can never be complete. ${ }^{28}$ The ensuing tensions and limitations lead to a number of outcomes that characterise financialised accumulation. These include the diffusion of a peculiar form of short-termism in economic decisions (e.g., not only through purely speculative activities but also through securitisable long-term investment, with pursuit of immediate profitability at the expense of productivity growth) ${ }^{29}$ the imperative for 
generating and appropriating surplus out of finance; and the explosive growth of rewards to high-ranking capitalists and managers in every sector, especially finance itself, fuelling the concentration of income under neoliberalism. These financialised forms of accumulation are mutually reinforcing, but they can also dysfunctionally diverge (see twelfth thing).

The relations of mutual determination between finance and economic and social reproduction, identified above, establish the material basis of neoliberalism as a system of accumulation, described in the first thing. ${ }^{30}$ In turn, financialisation has supported the global restructuring of production, that has become known as 'globalisation', and the reconstitution of US imperialism in the wake of the collapse of the Bretton Woods System, the US defeat in the Vietnam War and the Iranian revolution. ${ }^{31}$

This understanding of financialisation has four significant implications. First, financialisation underpins neoliberalism analytically, economically, politically and ideologically, and it has been one of the main drivers of the restructuring of the global economy since the 1970s; financialisation is, then, the defining feature of the forms taken today by accumulation and economic and social reproduction. Second, financialisation has been buttressed by institutional transformations expanding and intensifying the influence of finance over the economy, ideology, politics and the state. Third, contemporary financialisation derives both from the post-war boom and from its collapse into the stagflation of the $1970 \mathrm{~s} .{ }^{32}$ Fourth, financialisation has been closely associated with the increasing role of speculative finance in economic and social reproduction, not least through privatisation of public utilities and, more recently, public-private partnerships in provision of economic and social infrastructure. 
The sixth thing you need to know about neoliberalism is that it does not merely involve a change in policies that, in principle, could be readily reversed.

The neoliberal 'policy reforms' implemented through Reaganism, Thatcherism and the (post-)Washington Consensus are supported by five ontological planks. ${ }^{33}$ First is the dichotomy between markets and the state, implying that these are rival and mutually exclusive institutions. Second is the assumption that markets are effective if not efficient while state intervention is wasteful because it distorts prices and misallocates resources in comparison with what an ideal market would have done, induces rent-seeking behaviour and fosters technological backwardness. Third, the belief that technological progress, the liberalisation of finance and capital movements, the systematic pursuit of 'shareholder value' and successive transitions to neoliberalism around the world have created a global economy characterised by rapid capital mobility within and between countries and (an ill-defined process of) 'globalisation'. Where they are embraced, rapid growth ensues through the prosperity of local enterprise and the attraction of foreign capital; in contrast, reluctance or 'excessive' state intervention (however it may be determined) drives capital, employment and economic growth elsewhere. Fourth, the presumption that allocative efficiency, macroeconomic stability and output growth are conditional upon low inflation, which is best secured by monetary policy at the expense of fiscal, exchange rate and industrial policy tools. Fifth, the realisation that the operation of key neoliberal macroeconomic policies, including 'liberalised' trade, financial and labour markets, inflation targeting, central bank independence, floating exchange rates and tight fiscal rules is conditional upon the provision of potentially unlimited state guarantees to the financial system, since the latter remains 
structurally unable to support itself despite its escalating control of social resources under neoliberalism.

Neoliberalism has not only changed the policies adopted by governments but also the conditions within which policy is conceived, formulated, implemented, monitored and responded to. This has been recognised clearly, if partially, in the literatures that seek to distinguish different types of capitalism. ${ }^{34}$ For example, the Varieties of Capitalism (VoC) approach perceives differences in the institutional construction of policy and, in the case of social policy, the Welfare Regimes Approach (WRA) focuses on the balance of power and resources between capital and labour and how they are mediated through (influence upon) the state. Presumably, each of these approaches would emphasise the encroaching gains of neoliberal capitalism, although neither was originally grounded upon the changing role of finance in specifying the varieties and regimes, respectively, and their evolving fortunes. ${ }^{35}$ Instead, these approaches are caught on the intellectual cusp between the post-war boom and neoliberalism, seeking to defend or promote what is perceived to be the best of the past (boom) against the worst of what was yet to come, itself extrapolated from the past as a less successful liberal form of post-war capitalism.

That neoliberalism is not reducible to changes in macroeconomic policy is not a novel insight, as neoliberalism has, often, been defined instead by microeconomic shifts, not least through privatisation and commercialisation as symptomatic of the presumed withdrawal of state intervention. However, such distinctions between the microeconomic and the macroeconomic cannot generally be sustained not least as, for example, the provision of economic and social infrastructure straddles both, as do trade, industrial, commercial and, not least, financial policy. Our interpretation of neoliberalism as grounded upon finance-driven 
economic and social restructuring can encompass both (admittedly parodied) extremes of micro and macro shifts, integrate them and develop their insights further.

7

The seventh thing you need to know about neoliberalism is that it represents more than a shift in the balance of power, primarily against labour and in favour of capital in general and of finance in particular, undoubtedly true though this is.

Neoliberalism invariably has a significant impact on class relations and the distributional balance between them, for example, through financialisation, globalisation and neoliberal reforms. This includes the 'flexibilisation' and intensification of labour, the limitation of wage growth, the rollback of collective bargaining and the adverse changes in the welfare regime, and how each of them has affected workers, women, minorities, immigrants, and so on. Neoliberalism has also affected social relations through privatisation and the appropriation of the 'commons' (i.e., areas where property rights were either absent or vested upon the state), ${ }^{36}$ and through the financialisation of social reproduction (see eleventh thing). Finally, neoliberalism has triggered macroeconomic crises that penalise the poor disproportionately (see twelfth thing). ${ }^{37}$ In these ways, neoliberalism has both expanded the power of capital and created an income-concentrating dynamics of accumulation that can be limited, but not reversed, by marginal (Keynesian) interventions.

These shifts in the balance of power are both symbolic of the establishment of neoliberalism and fundamental to its reproduction, with the anti-labour policies and assaults of Reaganism and Thatcherism to the fore. These are so significant that, especially in US 
political economy literature, they are often taken to be the defining characteristic of neoliberalism, with financialisation as its consequence. ${ }^{38}$ This argument follows from an analysis of neoliberalism primarily in distributional terms, suggesting that lower economic and social wages cause high inequality as well as deficient demand, to which speculative finance is a corollary through both investment by the wealthy and the expansion of credit to the poor (for consumption, mortgages, and other short-term responses to wage compression). This is, however, to reduce economic and social restructuring in general, and neoliberalism specifically, to the spheres of circulation (effective demand) and distribution (between wages and profits). In the context of specifying both the balance and the nature of power under neoliberalism, this is too limited, and it extrapolates unduly from US (and, to some extent, UK) conditions.

This point can be made by reference to what might be termed the social compacting paradigm (SCP), which has been deployed to characterise economic and social 'settlements' over the post-war boom, typically in order to explain comparative national performance: for example, why did West Germany and Japan grow faster than the USA or the UK. ${ }^{39}$ SCP suggests that formal and institutionalised negotiation between capital and labour offered fuller and stronger labour representation in policymaking, and that the social partnership agreement around wage restraint in return for expanding social wages induced higher investment and faster productivity growth than the Anglo-Saxon paradigm.

Irrespective of the extent to which differential performance across countries can be explained primarily by industrial relations,${ }^{40}$ however broadly conceived, the contrast with the neoliberal period is striking. The weakening power of labour has led to, and been reflected by, its systematic exclusion from policymaking. Consequently, social compacting 
has itself been widely dismantled and, where it has survived, it has shrivelled into a tokenistic ritual or illusory role of legitimation of neoliberal policies addressing the implications of faltering growth, rather than negotiating the distribution of gains due to productivity, output and income growth. Most importantly, financial policy and the functioning of the financial system invariably remain outside the scope of any social compacting. ${ }^{41}$

Such considerations are well-illustrated by examples in Eastern Europe and South Africa where, with the collapse of the Soviet regime and apartheid, respectively, in the early nineties, neoliberalism both arrived late and sought to make up for lost time. Necessarily, the forms taken by policymaking and the powers underpinning and exercised through the transition to neoliberalism were subject to considerable variation across countries and over time, and were hardly reducible to a shift from the state to the market (see fourth thing). For example, whilst forms of tripartism flourished in post-Soviet Eastern Europe, their content was eviscerated as they were used to ease the emergence of new elites and consolidate the old in new circumstances. Consequently, in these neoliberal experiences reliance upon, or marginalisation, of tripartism has been a matter of convenience, leading to an 'illusory corporatism' that bears little relationship either to the post-war boom social corporatism in the West or to the influence of, and support for, labour characteristic of the Soviet period. ${ }^{42}$

A similar account can be told of South Africa, where the form taken by social corporatism is the Triple Alliance of the ANC, the South African Communist Party and COSATU, the confederation of trade unions. Yet, the ANC Government is generally recognised as having taken a neoliberal turn in the mid-1990s, not least with the adoption of the Growth, Employment and Redistribution (GEAR) policy framework. As the economy was thoroughly restructured through financialisation during the post-apartheid period, the 
main forum for tripartite policymaking, the National Economic Development and Labour Council (NEDLAC), became increasingly ineffective because of the non-participation of the most powerful businesses and lack of influence over major policies and issues, especially those involving finance. ${ }^{43}$ In short, social compacting under neoliberalism, if and when it occurs, actually undermines the labour movement, and much the same is liable to be so of new social movements, in and of themselves, in the absence of strong and supportive left movements and organisations.

8

The eighth thing you need to know about neoliberalism is that it involves varied and shifting combinations of scholarship, ideology, policy and practice, with connections but not necessarily coherence across and within these elements. ${ }^{44}$

The tensions across these domains can be illustrated at three levels. First, the meaning and significance of neoliberal scholarship, the ensuing ideology and their policy implications have shifted across time, place and issue, and there can be inconsistencies across their component parts. These are, often, due to tensions between the rhetorical and policy worlds built by the advocates of neoliberalism, and the realities of social and economic reproduction. The most striking example is provided by the shift from privatisation to public-private partnerships, especially where large-scale state support for private provision of economic and social infrastructure is concerned. ${ }^{45}$

Second, even the most ardent supporter of freedom of the individual in general, and market freedom in particular, concedes that those freedoms can only be guaranteed through 
state provision of, and coercion for, a core set of functions and institutions, ranging over fiscal and monetary policy to law and order and property rights, through to military intervention to secure the 'market economy' when this becomes necessary. In practice, then, neoliberalism can be closely associated with authoritarianism, while its attachment to classical liberalism and political democracy is hedged and heavily conditional in practice (see second thing). ${ }^{46}$

Third, the tensions and inconsistencies across scholarship, ideology, policy and practice were sharply revealed by the policy responses to the current crisis, with the ideology of free markets, especially those of finance, smoothly giving way to heavy intervention on its behalf, what has been dubbed socialism for the bankers and capitalism for the rest of us, followed by a bewildered response from the discipline of economics to events that were not so much unpredicted as deemed to be either impossible or subject to policy control. Paradoxically, while unlimited resources have been made available to salvage finance, no concession has been offered at the level of ideology or scholarship, where the intolerant hegemony of mainstream economics remains virtually unscathed.

The ninth thing you need to know about neoliberalism is that it has been subject to two phases, loosely divided by the early 1990s.

The first phase of neoliberalism is aptly characterised as the transition or shock phase, in which the promotion of private capital proceeded in country after country without regard to the consequences. This phase requires forceful state intervention to contain labour, 
disorganise the left, promote the transnational integration of domestic capital and finance and put in place new institutional frameworks (see first and third things).

The second (mature) phase has been, if only in part, a reaction to the dysfunctions and adverse social consequences of the first phase, not least in social welfare provision. This ('third wayist') phase focuses on the stabilisation of the social relations imposed in the earlier period, the consolidation and continued expansion of the financial sector's interventions in economic and social reproduction, state management of the new modalities of international economic integration, and the introduction of specifically neoliberal social policies both to manage the deprivations and dysfunctions created by neoliberalism and to consolidate and reconstitute social and individual agents along neoliberal lines (see tenth thing).

Both phases require extensive (re-)regulation, despite the rhetorical insistence of all manner of neoliberals on the need to 'roll back' the state, interpreted, in the first phase of neoliberalism, as 'hollowing out', followed by the 'rolling out' of new and, occasionally, more explicit forms of intervention on that foundation in the second phase (see fourth thing). Inevitably, these phases are more logical than chronological, as they can be sequenced, delayed, accelerated, or even overlain in specific ways depending on country, region and economic and political circumstances.

10

The tenth thing you need to know about neoliberalism is that it is highly variegated in its features, impact and outcomes. 
Although neoliberalism has an identifiable material and ideational core (see first, second and fifth things), and neoliberal policies share readily recognisable features, neoliberal experiences take a wide variety of forms in different countries and over time (see ninth thing). There are three reasons for this. First, despite its common core, neoliberalism can be associated with significant differences in the forms, degrees and impact of financialisation, the depth and modalities of internationalisation of production and dependence on external trade, societal changes, ideology, structures of political representation, and so on.

Second, these variegated relationships interact among themselves and with specific aspects of economic and social reproduction in historically contingent ways. Thus, for example, the more or less universal expansion of mortgage markets has interacted with the pre-existing housing systems in different ways across countries.

Third, whilst financialisation is a core aspect of neoliberalism, it remains not only uneven but also confined in its direct grasp over economic and social reproduction - not everything is financialised even where finance or even just the market is present. Thus, many public services are not commercialised, let alone financialised. As a result, even though financial institutions may not directly dictate how these services are provided, this does not mean that financialisation exerts no influence. The result is to create space for diversity in deviating not only from exclusive reliance upon financial imperatives where they do apply (such as the extent and level of user charges, for example) but also, and inevitably, where they do not. ${ }^{47}$ 
In sum, while the secular rise of financialisation and its extended reach across both economic and social reproduction is what motivates our understanding of neoliberalism as the current stage of capitalism (see first and fifth things), the impact of financialisation is variegated across industrial production and other types of enterprise, and so on. ${ }^{48}$ Concretely, whilst financialisation feeds in part by transforming economic and social activity in ways in which the associated revenues can be packaged into corresponding assets), the extent and influence of financialisation across the various elements of economic and social reproduction are highly contingent, reinforcing the variegated nature of outcomes. In short, economic and social reproduction cannot be reduced to financialisation, but nor is the latter entirely absent of influence where it is not present. ${ }^{49}$

With the increasing role of financialisation, whether directly or indirectly, there will remain dysfunctions and dissonances where the logic of the market does not prevail, most obviously with the hard to employ, house, educate, provide for in old age, raise out of poverty, provide for health, and so on. This is to raise the issue for neoliberalism of how to intervene where the market fails or is absented and which, in practice, is necessarily contingent upon how markets and the non-market are formed and contested. Such issues are obvious in case of social policy but by no means confined to it where for example, neoliberal ideology of (un)deserving poor dovetails with support for those in or into work. Precisely because dysfunctions in the hard to serve through the market are multi-dimensional and uneven in their incidence, individual anomalies are liable to be created across them either in the form of 'undue' benefits (to be cut) or 'undue' harshness (to be alleviated). In the context of chronic increases in inequality and the acute impact of crisis and recession, ${ }^{50}$ there are inevitable pressures both to reduce individual and overall benefits and to protect the most 
vulnerable, even if this contest can be highly uneven. How these and other tensions within neoliberalism are resolved is not pre-determined.

Somewhat different considerations apply where the forms taken by neoliberal economic and social reproduction are of more direct interest to the various fractions of capital than moderating social conflict and dysfunction in general. The state has long intervened to represent the interests of particular capitals, against the interests of others and, in some respects, for capital as a whole against the potentially destructive impact of competition between capitals. This remains the case under neoliberalism and implies that the state does not privatise everything, does not rely exclusively on private finance, and can even exclude such in order to pursue other interests and dynamics not least those of productive capital (on which financialisation in other spheres may heavily depend). Nonetheless, such interventions tend to be marked by the neoliberal condition, especially where private and/or international finance is involved, whether directly or indirectly, or even where it is absent because, for example, of continuing state provision (itself to be contingently explained and related to the broader role of finance, not least in funding the state and influencing its policies).

Whilst the current grip of neoliberalism raises doubts about the strength and viability of social resistance against the commodification of 'sacred' types of provision (including public goods and the environment), our perspective is distinctive in two respects. On the one hand, there is a social content to all objects of provision, including commodities, and each is open to particular types of reaction against market forms as is evident, for example, in the differences between housing, water, transport and health, and the wide variety of the targets of charity, from food banks to woodlands to opera. On the other hand, the dualism between neoliberal (re-)commodification and decommodification under, despite or against 
neoliberalism, is too crude. In other words, simply focusing on market forms is insufficient because these are far from homogeneous, ${ }^{51}$ as they can reflect everything from production for profit to user charges with (more or less targeted) subsidies, and obliterating the ways in which commodities serve provision along the chains of activities that attach production to the market.

11

The eleventh thing you need to know about neoliberalism is that its economic and social reproduction is attached to particular material cultures that give rise to what might be termed the (variegated) neoliberalisation of everyday life.

It was consistently shown by the previous things that neoliberalism has redefined the relationship between the economy, the state, society and individuals. It has constrained the latter to give their lives an entrepreneurial form, subordinated social intercourse to economic criteria, and neutered the previous structures and institutions of political representation. The ideology of self-responsibility has been especially significant since it deprives the citizens of their collective capacities, agency and culture, values consumption above all else, places the merit of success and the burden of failure on isolated individuals, and suggests that the resolution of every social problem requires the further individualisation and financialisation of social provision and intercourse.

The scholarly literature has pinpointed these features of neoliberalism in different ways, for example, through the idea that finance 'exploits us all' ${ }^{52}$ This notion draws upon, first, the intuition that low and stagnant wages, high unemployment, privatisation of basic 
services and the introduction of user charges have undermined the ability of many to sustain customary or desired living standards in the absence of credit, so that exploitative indebtedness results by way of (strictly temporary) remedy. Second, it is seemingly validated by the proliferation of financial relationships and institutions into daily life under neoliberalism. Such a perspective contains an element of truth in that financialisation has been associated with increasing inequalities of access and with volatility and insecurity in the provision of many aspects of economic and social life, with the potential for deprivation to be mutually compounding and multi-dimensional. But the nature and incidence of such deprivations are far from uniform across different social strata, age groups and areas of provision, and it is doubtful that the financialisation of everyday life is primarily characterised by exploitative indebtedness.

A broader approach suggests that the financialisation of daily life is better understood in terms of the subjection (which may or may not include relations of exploitation) of households to financial markets and processes. For example: ${ }^{53}$

$[\mathrm{H}]$ ouseholds have become a frontier of capital accumulation, not just as producers and consumers, but also as financial traders ... The requirements of this emergent financial citizenship for the house and households extend beyond just honouring payments on a home purchase, it is requiring a culture of financial calculation that becomes absorbed as part of the daily norms and dispositions of social being.

However, this framing immediately begs the question of which activities attached to the household are subject to a culture of (financial) calculation, why and how, and whether (in the absence of profit as the bottom line) they cohere into an integral system including both 
calculation and stable trade-offs. In turn, the corresponding social norms of financial behaviour are highly contingent upon the extent to which financialised forms of provision are prevalent, and what are the norms for provision of what is not financialised. ${ }^{54}$ Inevitably, then, across commodity consumption, housing, education, health, transport and so on, the impact of financialisation will be highly uneven and differentiated and far from reducible to, nor even primarily influenced by, an increasing presence of financial calculation.

A more promising approach can be rooted in the work of Foucault in seeing the neoliberalisation of everyday life - including the financialisation of social intercourse - as the subjective, if resisted and reflexive, internalisation of specifically neoliberal norms and dispositions. ${ }^{55}$ For Dardot and Laval (2013, p.8):

Neoliberalism is not merely destructive of rules, institutions and rights. It is also productive of certain kinds of social relations, certain ways of living, certain subjectivities ... This norm enjoins everyone to live in a world of generalized competition; it calls upon wage-earning classes and populations to engage in economic struggle against one another; it aligns social relations with the model of the market; it promotes the justification of ever greater inequalities; it even transforms the individual, now called on to conceive and conduct him- or herself as an enterprise. For more than a third of a century, this existential norm has presided over public policy, governed global economic relations, transformed society, and reshaped subjectivity. The circumstances of its triumph have often been described - in its political aspect (the conquest of power by neoliberal forces), its economic aspect (the expansion of globalized financial capitalism), its social aspect (the individualization 
of social relations to the detriment of collective solidarities, the extreme polarization between rich and poor), and its subjective aspect.

Even though this is more than an agenda of what needs to be discovered than discovery itself it suggests, once again, that the content of, and pathways to, neoliberalisation and the responses to it are highly diverse.

12

The twelfth thing you need to know about neoliberalism is that it is associated with specific modalities of economic growth, volatility and crisis.

The neoliberal restructuring of economic reproduction introduces mutually reinforcing policies that dismantle the systems of provisioning established previously (which are defined, often ex post, as being 'inefficient'), reduce the degree of coordination of economic activity, create socially undesirable employment patterns, feed the concentration of income and wealth, preclude the use of industrial policy instruments for the implementation of socially determined priorities, and make the balance of payments structurally dependent on international flows of capital. In doing this, and despite ideological claims to the contrary, neoliberalism fuels unsustainable patterns of production, employment, distribution, consumption, state finance and global integration, and it increases economic uncertainty, volatility and vulnerability to (financial) crisis.

In particular, financial sector control of economic resources and the main sources of capital allows it to drain capital from production; at the same time, neoliberalism 
systematically, if unevenly, favours large capital at the expense of small capital and the workers, belying its claims to foster competition and 'level the playing field'. As a result, accumulation in neoliberal economies tends to take the form of bubbles which eventually collapse with destructive implications and requiring expensive state-sponsored bailouts. These cycles include the international debt crisis of the early 1980s, the US savings and loan crisis of the 1980s, the stock market crashes of the 1980s and 1990s, the Japanese crisis dragging on since the late 1980 s, the crises in several middle-income countries at the end of the twentieth century, and the dotcom, financial and housing bubbles of the 2000s, culminating with the global meltdown starting in 2007.

In turn, neoliberal policies are justified ideologically through the imperatives of 'business confidence' and 'competitiveness'. This is misleading, because confidence is elusive, materially ungrounded, self-referential and volatile, and it systematically leads to the over-estimation of the levels and effectiveness of investments that will ensue from the pursuit of finance-friendly policies. Moreover, those policies are not self-correcting. Instead of leading to a change of course, failure to achieve their stated aims normally leads to the deepening and extension of the 'reforms' with the excuse of ensuring implementation and the promise of imminent success the next time around. ${ }^{56}$

Unsurprisingly, then, however we interpret the differences between the post-war boom (including Keynesianism, developmentalism, Soviet regimes and their variants) and the neoliberal period, economic performance for the latter in terms of growth and volatility has been generally worse and, ultimately, led to a global crisis driven by finance and financialisation, despite unambiguously and unprecedentedly favourable conditions for capitalism worldwide (see first thing). 
The thirteenth thing you need to know about neoliberalism is that there are alternatives, both within and beyond neoliberalism itself.

It was shown in the sixth thing that neoliberalism cannot be reduced to a collection of policies, which would suggest that alternative policy initiatives can reverse the neoliberal reforms and even transcend neoliberalism. Policy changes are certainly essential, but the scope for such changes can be questioned in the light of the political means available to the opposition, the strength of the coalitions potentially committed to them, and the scope to drive the required distributional, regulatory and policy reforms given the neoliberal transformation of production, international integration, the state, ideology and society itself. None of these can be adequately assessed without a prior understanding of the systemic features of neoliberalism and the transformations that it has wrought on class relations and institutions and the processes of economic and social reproduction.

It was also shown in the seventh thing that neoliberalism is not a 'capitalist conspiracy' against the workers, in which case there would be nothing systemic or historically-specific about it, since capitalists and the state have always readily conspired against the workers. ${ }^{57}$ Conversely, in this case neoliberalism could be dislocated through a counter-conspiracy, or even by changes in the law. Alternatively, this approach can also be read as implying that 'things were much better' under previous systems of accumulation (Keynesian, developmentalist, and so on), which, in principle, should be restored. 
The latter goals are laudable but implausible. For, while neoliberalism is incompatible with economic democracy, it simultaneously hollows out political democracy. ${ }^{58}$ On the one hand, the discourse and practice of TINA (There Is No Alternative), often now muted and implicit, under neoliberalism blocks the political expression of dissent even in moderate forms and feeds apathy, populism and the far right, courting destabilising implications for neoliberalism itself. On the other hand, the institutional shifts, the changes in the structures of political representation, and the social and economic transformations wrought by neoliberalism systematically reduce the scope for the expression of collective interests, the emergence of transformative programmes, and even the aspiration to change society beyond neoliberalism.

In short, the post-war consensus inspired a political contest over whether collectivism in the forms of (Keynesian) reformism or socialist revolution would be capable of continuing to deliver progressive outcomes. Neither now is on the agenda, not least as the dominant form taken by collective economic and social reproduction has been appropriated by finance. Nevertheless, the economic contradictions of neoliberalism, the incremental sclerosis of the political institutions regulating its metabolism and the cumulative corrosion of its ideological foundations make this system of accumulation resistant to economic change, but also vulnerable to a multiplicity of political challenges.

This does not imply that electoral strategies are sufficient, nor that changes in social, industrial, financial or monetary policies can fulfil radical expectations. Quite the contrary: neoliberalism has repeatedly demonstrated its resilience both in practice and in the realm of ideas. But the demand for the expansion and radicalisation of political and economic 
democracy can integrate widely different struggles, delegitimise neoliberalism and support the emergence of alternatives. These are now urgently needed.

\section{Acknowledgements:}

Kate Bayliss and Mary Robertson were major contributors to the ideas contributing to the drafting of this paper but declined to be co-authors. Thanks to others for comments.

\section{Funding acknowledgement:}

No funding received.

\section{For correspondence:}

Ben Fine, Department of Economics, SOAS, University of London, UK. Email: bf@soas.ac.uk

Alfredo Saad-Filho, Department of Development Studies, SOAS, University of London, UK. Email: as59@soas.ac.uk 


\section{References}

Aalbers, M and Christophers, B (2014) 'Centring Housing in Political Economy, Housing', Housing, Theory and Society, 31 (4), pp.373-394.

Albo, G (2008) 'Neoliberalism and the Discontented', in L. Panitch and C. Leys (eds) Socialist Register, London: Merlin Press.

Ashman, S and Fine, B (2013) 'Neo-liberalism, Varieties of Capitalism, and the Shifting Contours of South Africa's Financial System', Transformation, 81-82, pp.145-178. Ayers, A and Saad-Filho, A (2014) 'Democracy Against Neoliberalism: Paradoxes, Limitations, Transcendence', Critical Sociology, online first., http://crs.sagepub.com/content/early/2014/02/03/0896920513507789.abstract Bayliss, K and Fine, B (eds) (2008) Whither the Privatisation Experiment?: Electricity and Water Sector Reform in Sub-Saharan Africa. Basingstoke: Palgrave Macmillan. Bayliss, K, Fine, B and van Waeyenberge, E (eds) (2011) The Political Economy of Development: The World Bank, Neo-Liberalism and Development Research, London: Pluto Press.

Bellamy Foster, J and McChesney, RW (2012) The Global Stagnation and China, http://monthlyreview.org/2012/02/01/the-global-stagnation-and-china\#en49 Birch, K and Mykhnenko, V (2010) 'Introduction: A World Turned Right-Way Up', in The Rise and Fall of Neoliberalism: The Collapse of an Economic Order? London: Zed Books. Bryan, D and Rafferty, M (2014) 'Political Economy and Housing in the Twenty First Century - From Mobile Homes to Liquid Housing', Housing, Theory and Society 31 (4), pp.404-412.

Burgin, A (2012) The Great Persuasion: Reinventing Free Markets since the Depression. Cambridge, MA: Harvard University Press. 
Cahill, D (2013) 'Ideas-Centred Explanations of the Rise of Neoliberalism: A Critique', Australian Journal of Political Science, 48 (1), pp.71-84.

Cahill, D (2014) The End of Laissez-Faire? On the Durability of Embedded Neoliberalism. Cheltenham: Edward Elgar.

Callinicos, A (2001) Against the Third Way. London: Polity Press.

Castree, N (2006) 'Commentary’, Environment and Planning A, 38 (1), pp.1-6.

Chang, H-J (2011) 23 Things They Don't Tell You About Capitalism, London: Penguin.

Chang, K-S, Fine, B and Weiss, L (eds) (2012) Developmental Politics in Transition: The Neoliberal Era and Beyond, Basingstoke: Palgrave Macmillan.

Coe, N, Lai, P and Wójcik, D (2014) 'Integrating Finance into Global Production Networks' Regional Studies, 48 (5), pp.761-777.

Crouch, C (2009) 'Privatised Keynesianism: An Unacknowledged Policy Regime', British Journal of Politics and International Relations, 11 (3), pp.382-399.

Dale, G (2012) 'Double Movements and Pendular Forces: Polanyian Perspectives on the Neoliberal Age', Current Sociology, 60 (1), pp.3-27.

Dardot, P and Laval, C (2013) The New Way of the World: On Neoliberal Society, London: Verso.

Doherty, M (2011) 'It Must Have Been Love ... But It's over Now: The Crisis and Collapse of Social Partnership in Ireland', European Review of Labour and Research, 71 (3), pp.371385.

Duménil, G and Lévy, D (2004) Capital Resurgent: Roots of the Neoliberal Revolution. Cambridge, Mass.: Harvard University Press.

Duménil, G and Lévy, D (2011) The Crisis of Neoliberalism. Cambridge, MA: Harvard University Press. 
Ferguson, J (2007) 'Formalities of Poverty: Thinking about Social Assistance in Neoliberal South Africa', African Studies Review, 50 (2), pp.71-86.

Fine, B (2010a) Theories of Social Capital: Researchers Behaving Badly, London: Pluto Press.

Fine, B (2010b) “Zombieconomics: The Living Death of the Dismal Science”, in K Birch and V Mykhnenko (eds) The Rise and Fall of Neoliberalism: The Collapse of an Economic Order? London: Zed Books.

Fine, B (2010c) ‘Locating Financialisation’, Historical Materialism, 18, (2), pp. 97-116.

Fine, B (2013-14) 'Financialisation from a Marxist Perspective', International Journal of Political Economy, 42 (4), pp.47-66.

Fine, B (2013a) Towards a Material Culture of Financialisation, FESSUD Working Paper Series, no 15, http://fessud.eu/wp-content/uploads/2013/04/Towards-a-Material-Culture-ofFinancialisation-FESSUD-Working-Paper-15.pdf

Fine, B (2013b) ‘Consumption Matters’, Ephemera, 13 (2), pp.217-248, http://www.ephemerajournal.org/contribution/consumption-matters.

Fine, B (2014a) 'Across Developmental State and Social Compacting: The Peculiar Case of South Africa', unpublished manuscript.

Fine, B (2014b) 'The Continuing Enigmas of Social Policy', prepared for the UNRISD project on Towards Universal Social Security in Emerging Economies, UNRISD Working Paper 2014-10, http://www.unrisd.org/Fine.

Fine, B and Dimakou, O (2016) Macroeconomics: A Critical Companion. London: Pluto Press.

Fine, B and Hall, D (2012) “Terrains of Neoliberalism: Constraints and Opportunities for Alternative Models of Service Delivery", in DA McDonald and G Ruiters (eds) Alternatives to Privatisation. London: Routledge. 
Fine, B and Harris, L (1985) The Peculiarities of the British Economy. London: Lawrence and Wishart.

Fine, B and Milonakis, D (2009) From Economics Imperialism to Freakonomics: The Shifting Boundaries Between Economics and Other Social Sciences. London: Routledge.

Fine, B and Milonakis, D (2011) “"Useless but True”: Economic Crisis and the Peculiarities of Economic Science', Historical Materialism, 19 (2), pp.3-31.

Fine, B and Saad-Filho, A (2014) 'Politics of Neoliberal Development: Washington Consensus and post-Washington Consensus' in H Weber (ed) Politics of Neoliberalism. London: Routledge.

Fine, B, Johnston, D, Santos, A and Van Waeyenberge, E (2016) 'Nudging or Fudging: The World Development Report 2015', Development and Change, 47 (4), forthcoming. Fine, B, Lapavitsas, C and Pincus, J (eds) (2001) Development Policy in the Twenty-first Century: Beyond the Post-Washington Consensus. London: Routledge.

Fine, B, Saraswati, J and Tavasci, D (eds) (2013) Beyond the Developmental State: Industrial Policy into the $21^{\text {st }}$ Century. London: Pluto.

Gingrich, J (2015) 'Varying Costs to Change? Institutional Change in the Public Sector', Governance, 28 (1), pp.41-60.

Gowan P (1999) The Global Gamble: America's Faustian Bid for World Dominance. Verso: London.

Graeber, D (2014) 'Anthropology and the Rise of the Professional-Managerial Class', Journal of Ethnographic Theory, 4 (3), pp.73-88.

Hands, D (2010) 'Economics, Psychology and the History of Consumer Choice Theory', Cambridge Journal of Economics, 34 (4), pp.633-648.

Hart, G. (2002) Disabling Globalization: Places of Power in Post-Apartheid South Africa. Durban: University of Natal Press. 
Hart, G (2008) 'The Provocations of Neoliberalism: Contesting the Nation and Liberation after Apartheid', Antipode, 40 (4), pp.678-705.

Harvey, D (2005) A Brief History of Neoliberalism. Oxford: Oxford University Press.

Kiely, R (2005) The Clash of Globalisations: Neo-Liberalism, the Third Way and Anti-

Globalisation. Leiden: Brill.

Kliman, A and Williams, S (2015) 'Why “Financialisation” Hasn't Depressed US Productive Investment', Cambridge Journal of Economics, 39 (1), pp.67-92.

Kotz, D (2015) The Rise and Fall of Neoliberal Capitalism. Cambridge, MA: Harvard University Press.

Kotz, D., T. McDonough, T. and Reich, M. (2010) (eds) Contemporary Capitalism and Its Crises: Social Structure of Accumulation Theory for the 21st Century. Cambridge: Cambridge University Press.

Kozul-Wright, R. (2006) ‘Globalization Now and Again', in K.S. Jomo (ed) Globalization under Hegemony: The Changing World Economy. Oxford: Oxford University Press.

Krippner, G. (2011) Capitalizing on Crisis: The Political Origins of the Rise of Finance. Cambridge, MA: Harvard University Press.

Labica, G (2007) 'From Imperialism to Globalisation', in S Budgen, S Kouvelakis and S Žižek (eds) Lenin Reloaded: Toward a Politics of Truth. Durham, N.C.: Duke University Press.

Langley, P (2008) The Everyday Life of Global Finance. Oxford: Oxford University Press. Lemke, T (2001) 'The Birth of Bio-Politics: Michel Foucault's Lecture at the Collège De France on Neo-Liberal Governmentality', Economy \& Society 30 (2), pp.190-207.

Madra, Y and Adaman, F (2014) 'Neoliberal Reason and Its Forms: De-Politicisation through Economisation', Antipode, 46 (3), pp.691-673. 
McNally, D (2014) Global Slump: The Economics and Politics of Crisis and Resistance. Oakland: PM Press.

Medema, S (2009) The Hesitant Hand: Taming Self-Interest in the History of Economic Ideas. Princeton: Princeton University Press.

Mills, CW (1959) The Sociological Imagination. Oxford: Oxford University Press.

Milonakis, D and Fine, B (2009) From Political Economy to Economics: Method, the Social and the Historical in the Evolution of Economic Theory. London: Routledge.

Mirowski, P (2009) 'Postface: Defining Neoliberalism' in P. Mirowski and D. Plehwe (eds) The Road from Mont Pèlerin: The Making of the Neoliberal Thought Collective. Cambridge, MA: Harvard University Press.

Mirowski, P and Plehwe, D (eds) (2009) The Road from Mont Pèlerin: The Making of the Neoliberal Thought Collective. Cambridge, MA: Harvard University Press.

Montgomerie, J (2009) 'The Pursuit of (Past) Happiness? Middle-class Indebtedness and American Financialisation', New Political Economy, 14 (1), pp.1-24.

Ost, D (2000) “'Illusory Corporatism’ in Eastern Europe: Neoliberal Tripartism and Postcommunist Class Identities', Politics and Society, 28 (4), pp.503-530.

Ost, D (2011) 'Illusory Corporatism Ten Years Later’, Warsaw Forum of Economic Sociology, 2 (1), pp.19-49.

Palma, G (2009) 'The Revenge of the Market on the Rentiers', Cambridge Journal of Economics, 33 (4), pp.829-869.

Panitch, L. and Gindin, S. (2012) The Making of Global Capitalism: The Political Economy of American Empire. London: Verso.

Panitch, L and Konings, M (2008) (eds) American Empire and the Political Economy of Global Finance. London: Palgrave. 
Polanyi-Levitt, K (2013) From the Great Transformation to the Great Financialization. London: Zed Books.

Polanyi, K (2001) The Great Transformation: The Political and Economic Origins of Our Time. Boston: Beacon Press.

Regan, A (2009) 'The Impact of the Eurozone Crisis on Irish Social Partnership: A Political Economic Analysis', ILO International Training Centre, http://www.ilo.org/ifpdial/information-resources/publications/WCMS_213211/lang-en/index.htm (accessed 23 May 2016).

Rosenberg, J (2000) The Follies of Globalisation Theory. London: Verso.

Rosenberg, J (2005) 'Globalization Theory: A Post Mortem', International Politics 42, pp.274.

Rude, C (2005) 'The Role of Financial Discipline in Imperial Strategy', in L Panitch and C Leys (eds) Socialist Register. London: Merlin Press.

Saad-Filho, A (2008) ‘Marxian and Keynesian Critiques of Neoliberalism’, in L Panitch, C Leys, G Albo and V Chibber (eds) Socialist Register, London: Merlin Press.

Saad-Filho, A (2011) 'Crisis in Neoliberalism or Crisis of Neoliberalism?' in L Panitch, G Albo and V Chibber (eds) Socialist Register. London: Merlin Press.

Saad-Filho, A (2014) 'The "Rise of the South"”, in L Pradella and T Marois (eds) Polarizing Development. London: Pluto Press.

Saad-Filho, A and Johnston, D (2005) 'Introduction', in: Neoliberalism: A Critical Reader. London: Pluto Press.

Saad-Filho, A and Yalman, G (eds) (2010) Transitions to Neoliberalism in Middle-Income Countries: Policy Dilemmas, Economic Crises, Mass Resistance, London: Routledge. 
Santos, AC (2014), 'Financial Literacy, Financialisation and Neo-liberalism', FESSUD

Working Paper Series, no 11, https://ideas.repec.org/p/fes/wpaper/wpaper11.html (accessed 23 May 2016).

Smith, A (2009) An Inquiry into the Nature and Causes of the Wealth of Nations. Available at: http://www.gutenberg.org/files/3300/3300-h/3300-h.htm (accessed 23 May 2016).

Stedman Jones, D (2012) Masters of the Universe: Hayek, Friedman, and the Birth of Neoliberal Politics. Princeton: Princeton University Press.

Wacquant, L (2009) The Neoliberal Government of Social Insecurity. Durham, NC: Duke University Press.

Wade, R (2013) ‘How High Inequality plus Neoliberal Governance Weakens Democracy’, Challenge, 56 (6), pp.5-37.

Webster, E, Joynt, K and Metcalfe, A (2013) Repositioning Peak-Level Social Dialogue in South Africa: NEDLAC into the Future. Johannesburg: NEDLAC.

Witztum, A (2013) Behavioural Economics, Game Theory and Das Adam Smith Problem, http://www.eshet.net/conference/paper_view.php?id=1012\&p=38 (accessed 23 May 2016). Zysman, J (1983) Governments, Markets and Growth. London: Cornell University Press. 


\title{
Notes:
}

\begin{abstract}
${ }^{1}$ Much of the neoliberal conundrum is neatly illustrated by Wacquant (2009, p.306):
'Neoliberalism is an elusive and contested notion, a hybrid term awkwardly suspended between the lay idiom of political debate and the technical terminology of social science, which moreover is often invoked without clear referent. For some, it designates a hard-wired reality... while others view it as a doctrine ... It is alternately depicted as a tight, fixed, and monolithic set of principles and programs that tend to homogenize societies, or as a loose, mobile, and plastic constellation of concepts and institutions adaptable to variegated strands of capitalism'.
\end{abstract}

${ }^{2}$ See, for example, Ayers and Saad-Filho (2008, 2014), Bayliss et al (2011), Chang, Fine and Weiss (2012), Fine (2010a, 2010b), Fine and Hall (2012), Fine and Saad-Filho (2014), SaadFilho (2003, 2007, 2008, 2011), Saad-Filho and Johnston (2005) and Saad-Filho and Yalman (2010).

${ }^{3}$ This paper does not draw upon material from those case studies, but relevant contributions are included in Work Packages 5 and 8 of the Fessud project, http://fessud.eu/

${ }^{4}$ See Dardot and Laval (2013), Mirowski and Plehwe (2009) and Stedman Jones (2012).

${ }^{5}$ Thus, for Dardot and Laval (2013, p.7), 'Since the late 1970s and early 1980s, neoliberalism has generally been interpreted both as an ideology and as an economic policy directly informed by that ideology'.

${ }^{6}$ See, for example, Duménil and Lévy (2004) and the works reviewed in Cahill (2014).

${ }^{7}$ Similar, if not identical, questions might be asked of 'globalisation' which is the most prominent way of characterising the contemporary world, not necessarily as a stage of 
development, but with multiple, competing, contested and not always consistent interpretations (Kiely, 2005; Kozul-Wright, 2006; Labica, 2007; Rosenberg, 2000, 2005).

${ }^{8}$ Of course, there may be exceptions if periodising by relatively disconnected criteria such as political systems, wars and technologies.

${ }^{9}$ This leaves open how to characterise the stage after Keynesianism if not neoliberalism, with post-Fordism also having proven incapable of delivering anything other than a temporary and unsatisfactory answer.

${ }^{10}$ See Castree (2006) and Ferguson (2007) but also, on the contrary, Hart (2002, 2008) for neoliberalism's contingent diversities as opposed to incoherencies.

${ }^{11}$ Bellamy Foster and McChesney (2012).

${ }^{12}$ See Ayers and Saad-Filho (2014), and note the putative 'de-politicisation through economisation' (Madra and Adaman, 2014). The neoliberal dilemma across freedom of, and yet control over, individual choice is neatly addressed in scholarship, ideology and, increasingly, policy in practice, by the notion of 'nudging' behaviour (Fine et al 2016).

${ }^{13}$ See Hands (2010) and Witztum (2013) for the poverty of the attempted socialisation of the individual in mainstream economics relative to Smith. Medema (2009) demonstrates the tension between appealing to pursuit of self-interest as a rationale both favouring and opposing state intervention.

${ }^{14}$ Following the decline of Friedman's monetarism in the 1980s, the emerging neoliberal ideas were strapped more or less awkwardly to different versions of 'supply-side' and new classical economics, new Keynesianism and new institutionalism, depending on how imperfectly working markets were conceptualised and incorporated into macroeconomic 
analysis (see Fine, Lapavitsas and Pincus 2001, Fine and Milonakis 2009, Milonakis and Fine 2009 and Fine and Dimakou 2016).

${ }^{15}$ See Duménil and Lévy (2004), Fine and Harris (1985) and, especially, Panitch and Gindin (2012).

${ }^{16}$ See Gowan (1999) and Saad-Filho (2007).

${ }^{17}$ See Fine and Milonakis (2009 and 2011).

${ }^{18}$ Most recently, see Kliman and Williams (2015).

${ }^{19}$ The most prominent example of this sort of reasoning is the Brenner hypothesis of investment overhang involving competitiveness between nations and large national capitals discouraging new investment. See, however, Fine et al (2005) for a critique focusing on the extraordinary restructuring in the steel industry. Hypotheses of lack of movement since the 1970s rarely can provide evidence from particular sectors of the economy for which, of course, little has remained the same.

${ }^{20}$ It is part and parcel of the inheritance from Keynesianism and its debate with monetarism that health, education, welfare, industrial policy, finance for investment, and so on, as opposed to effective demand, are sidelined alongside the focus on the short run as if it were independent from the long run. In this respect, monetarism only completed what Keynesianism started, finishing with the failure to acknowledge financialisation, itself merely the tip of the iceberg in the neglect of the other determinants of economic policy and performance. Hence the insights from and limitations of Crouch's (2009) notion of privatised Keynesianism, that neoliberalism is based upon demand management through private credit rather than state expenditure. 
${ }^{21}$ As Wade $(2013, \mathrm{p} .7)$ rightly puts it, "[t]he "market" is the polite way of referring to "the owners of capital", especially financial capital'.

${ }^{22}$ See, for example, Lemke (2001).

${ }^{23}$ See Fine et al (2013) in the context of the developmental state paradigm that accepts the analytical agenda of state versus market.

${ }^{24}$ See Bayliss and Fine (2008).

${ }^{25}$ See first thing and Fine (2013a).

${ }^{26}$ Quoting at length from Ashman and Fine (2013, pp.156-57): ‘[F]inancialisation has involved: the phenomenal expansion of financial assets relative to real activity; ... the proliferation of types of assets, from derivatives through to futures markets with a corresponding explosion of acronyms; the absolute and relative expansion of speculative as opposed to or at the expense of real investment; a shift in the balance of productive to financial imperatives within the private sector whether financial or not; increasing inequality in income arising out of weight of financial rewards; consumer-led booms based on credit; the penetration of finance into ever more areas of economic and social life such as pensions, education, health, and provision of economic and social infrastructure; the emergence of a neoliberal culture of reliance upon markets and private capital and corresponding anti-statism despite the extent to which the rewards to private finance have ... derived from state finance itself. Financialisation is also associated with the continued role of the US dollar as world money despite ... its deficits in trade, capital account, the fiscus, and consumer spending, and minimal rates of interest ... [H]owever financialisation is defined, its consequences have been perceived to be: reductions in overall levels and efficacy of real investment as financial instruments and activities expand at its expense even if excessive investment does take place in particular sectors at particular times; ... prioritising shareholder value, or financial worth, 
over other economic and social values; pushing of policies towards conservatism and commercialisation in all respects; extending influence of finance more broadly, both directly and indirectly, over economic and social policy; placing more aspects of economic and social life at the risk of volatility from financial instability and, conversely, placing the economy and social life at risk of crisis from triggers within particular markets ... Whilst, then, financialisation is a single word, it is attached to a wide variety of different forms and effects of finance.'

${ }^{27}$ Panitch and Konings (2008), Panitch and Gindin (2012) and Rude (2005).

${ }^{28}$ Fine (2013-14), Fine and Saad-Filho (2010, ch.12).

${ }^{29}$ Note that reducing wages in pursuit of profit is by no means unique to neoliberalism. But, for the latter, the pressure is that much greater in view of financial imperatives (also explaining why rewards within or linked to that sector have become so disproportionate).

${ }^{30}$ Albo (2008) and Saad-Filho and Johnston (2005).

${ }^{31}$ See, inter alia, Duménil and Lévy (2004), Gowan (1999) and Kotz (2015).

${ }^{32}$ For a historical overview see Panitch and Gindin (2012), Rude (2005) and Saad-Filho (2007).

${ }^{33}$ Saad-Filho and Johnston (2005).

${ }^{34}$ Thus, for example, the social structures of accumulation approach has been modified to suggest that neoliberalism is a particularly dysfunctional articulation of social structures (Kotz et al, 2010).

${ }^{35}$ See, in this light, Ashman and Fine (2013) and Fine (2014b) for critiques of VoC and WRA, respectively. Note that each approach to different types of (parts of) capitalism is 
grounded in methodological nationalism in which the global as such is just one factor amongst many.

${ }^{36}$ Harvey (2005) calls this process 'accumulation by dispossession', an umbrella term for an extremely diverse range of phenomena that at most and only occasionally has a limited connection to primitive accumulation in the classical Marxist sense and, more often than not, are underpinned by financialisation (as, for example, in futures carbon trading, which is probably the most fetishised form of dispossession).

${ }^{37}$ See, for example, Duménil and Lévy (2011) and McNally (2014).

${ }^{38}$ Thus, for the monopoly capital school, US capitalism has been chronically beset, even during the post-war boom, by deficient demand, in this case deriving from the underconsumption deriving from high monopoly prices, and correspondingly low real wages and output. For Polanyi Levitt (2013, p. 164): 'The objective of the neoliberal counterrevolution was to restore the discipline of capital over labour, and the principal means of achieving it were deregulation, liberalization, privatization and explicit attacks on trade unions'.

${ }^{39}$ For a critical review, see Fine (2014a).

${ }^{40}$ Significantly for what was to come, germane to comparative performance during the postwar boom were debates about different financial systems (typically, bank-based vs marketbased) and how conducive they were for economic and social restructuring, in both generating finance for investment and interacting with the policymaking processes (Ashman and Fine, 2013; Fine and Harris, 1985; Zysman, 1983).

${ }^{41}$ The leading example is provided by the Irish Republic, not least in the wake of the global crisis; see Doherty (2011) and Regan (2009). 
${ }^{42}$ For example, in Hungary, '[c]ommitted to introducing new fiscal discipline and to cutting real wages, the Socialist government unilaterally imposed it austerity budged and reinstituted wage controls, bypassing the IRC [Industrial Relations Code] while continuing to claim commitment to the tripartite process' (Ost 2000, p.510). In Poland, 'the main task of ... [the] tripartite commission has been to secure labor's consent to its own marginalization' (p.515). In sum, 'the best that can be said is that tripartism means formal negotiations over very broad issues, with no guarantees that the agreements will become law or be respected by employers ... equally likely are tripartite sessions where the government simply informs "social partners" of its intentions and seeks labor assent to fait accompli' (Ost 2000, p. 515).

${ }^{43}$ See Webster et al (2013).

${ }^{44}$ See, especially in the context of 'development', Bayliss et al (2011), Fine (2010a) and Fine and Saad-Filho (2014).

${ }^{45}$ See Bayliss and Fine (2008).

${ }^{46}$ See, for example, Barber (1995) and Bresnahan (2003).

${ }^{47}$ See Gingrich (2015) for variability in institutional forms of social provision in light of what is provided and how and corresponding implications for 'cost' of neoliberal change.

${ }^{48}$ Note that beyond the pursuit of the eponymous stakeholder value, study of the relationship between financialisation and the restructuring of productive capital remains seriously underdeveloped, partly because it is limited to drawing upon macroeconomic generalisations in terms of low investment. For a telling illustration in the context of financialisation of global production networks, see Coe et al (2014).

${ }^{49}$ See, for example, Graeber (2014) on the neoliberalisation of the university. 
${ }^{50}$ For the capacity of the top $10 \%$ of the income distribution to grow at the expense of the bottom 40\%, see Palma (2009) on the 'neoliberal art of democracy'.

${ }^{51}$ See Fine (2013)

${ }^{52}$ See especially Lapavitsas (2013) and Fine (2010c and 2013-14) for wide-ranging critique with alternatives.

${ }^{53}$ Bryan and Rafferty (2014, p.404).

${ }^{54}$ Such financialisation of everyday life directly leads to the notion that the over-indebted are in need of financial literacy programmes as a result of being irrational (see Santos, 2014).

${ }^{55}$ See, for example, Langley (2008) and Kear (2013).

${ }^{56}$ This is evident in the 'evaluatory trap' associated with privatisation (Bayliss and Fine, 2008) and in the hype surrounding private sector funding of the public sector.

${ }^{57}$ In Adam Smith's (2009) famous words, 'People of the same trade seldom meet together, even for merriment and diversion, but the conversation ends in a conspiracy against the public, or in some contrivance to raise prices'.

${ }^{58}$ Ayers and Saad-Filho (2014). 